Civil Society Organizations in the Informal Settlements of Buenos Aires:

Service Providers and Forces for Change

Ann Mitchell ${ }^{1}$

1 Department of Economics, Pontificia Universidad Católica Argentina, Alicia Moreau de Justo 1400, Ciudad Autónoma de Buenos Aires (1425) Argentina, annmitchell@uca.edu.ar, +541143490200 ext 7069. 


\section{Civil Society Organizations in the Informal Settlements of Buenos Aires: Service Providers and Forces for Change}

The objective of this paper is to analyze the historical roots and contribution to human development of civil society organizations in marginalized communities based on fieldwork undertaken in seven informal settlements of the City of Buenos Aires, Argentina. The paper provides evidence of a dense network of organizations whose principal function is the provision of social services, especially food assistance, through a complementary relationship with the state. The current effectiveness of the settlements' representative organizations-the principal vehicles through which community members voice their collective demands-is limited by a mix of factors intimately related to civil society-state relations, including irregularities in election processes, conflicts between organizations and lack of transparency in the allocation of public resources. The paper concludes that true empowerment of these communities to act as a unified force for change requires the strengthening of neighborhood organizations and greater government openness to civil society participation in public decision-making processes.

Key words: civil society-state relations, informal settlements, collective action, grassroots organizations, social service provision 


\section{Introduction}

The proliferation of informal settlements, rising inequality and increasing territorial concentration of poverty are problems shared by metropolises throughout the developing world. In 2012 an estimated 863 million people (33\% of the urban population) lived in slums worldwide, compared to 760 million in 2000 and 650 million in 1990 (UN-Habitat, 2013). Both governments and international organizations recognize the importance of engaging civil society in actions to improve the wellbeing of the inhabitants of urban slums. The United Nations Settlement Program, for example, has stated that "the progress of any action for human settlement development depends to a large degree on local authorities, civic engagement and the forging of partnerships at all levels of government with all relevant and competent stakeholders of civil society" (UN-Habitat, 2003b:7).

Diverse studies have presented evidence on the important and complex role of civil society organizations (CSOs) in urban informal settlements, both as service providers and as mobilizers of collective action (Campfens, 1997; UN-Habitat, 2003a; Donaghy, 2013). Some research has documented the proliferation of organizations in marginalized communities, often to attend the needs of the population in the face of reduced state support (Ekirapa et al, 2012; Garcia Delgado and De Piero, 2002; Rofman, 2010). Other researchers, however, have presented evidence of an erosion of networks of organizations and institutions in segregated communities marked by isolation and violence (Wacquant, 2008). Pereira-Leite (2008), for example, concludes that violence and ties between local organizations and criminal groups weaken social interaction and act as barriers to collective action in the favelas of Rio de Janeiro.

Moreover, there is not only debate over the density of the CSO sector in urban slum communities, but also disagreement over the extent to which local networks of organizations foster civic participation, promote democratic values and behavior and improve the wellbeing of community members. In contexts in which organizations are mostly concerned with securing resources for their own territory or for association members (Esposito Guevara, 2008; Meyer and Hyde, 2004) or when organization leaders act as brokers in clientelistic relationships between governments and community members (Magaloni et al., 2007; Molenaers, 2006), dense networks of neighborhood organizations may only weaken public trust and cooperation. There is clearly a need for more research—spanning different regions and historical contexts- 
on how organizations emerge and contribute to human development in urban slum communities.

This paper aims to analyze how civil society organizations contribute to human development in marginalized communities based on the results of organization and household surveys carried out in seven informal settlements of the City of Buenos Aires, Argentina. The paper seeks to respond to the following three research questions: What is the scale and structure of the civil society sector in the informal settlements? What factors motivate or hinder the process of collective action in this context? How do CSOs contribute to improving the lives of the residents of informal settlements?

These questions will be considered within the framework of the human development and capabilities approach. According to this approach, human development entails the expansion of individual capabilities and agency. Capabilities refer to the set of possible functionings that describe what a person can do and be (Sen, 1984). Individual functionings depend on access not only to money or material goods (that enable one to be well nourished or disease free, for example), but also non-material goods (such as to live free from fear or to be able to vote in elections). Agency refers to "the freedom to achieve whatever the person, as a responsible agent, decides he or she should achieve" (Sen, 1985:203-204). Value judgments about how to prioritize different dimensions of human life should be based on the aspirations and values of the people concerned, rather than the value system defined by government or the researcher.

From this perspective it becomes readily clear how civil society organizations can contribute to human development. Organizations can expand individual capabilities by providing them with essential goods or services. They can provide spaces in which members of society can interact, socialize, converse, and learn to empathize with one another, thereby expanding their capability for affiliation (Nussbaum, 2006: 59). But even more importantly, organizations can provide mediums through which individuals can become active agents in their lives, where through deliberation they can define which goals they most value and collectively work to pursue those goals. As Sen states “...human agency can deliberately bring about radical change through improving societal organization and commitment" (Alkire and Deneulin, 2010:28) 
The paper is organized as follows. It begins with a description of the methodology and data sources employed in the paper. Then the historical evolution of the informal settlements of the City of Buenos Aires and the socioeconomic characteristics of the population are described in order to provide context for the subsequent analysis of the civil society sector. The paper then uses data from the CSO survey to evaluate the density and structure of the civil society sector in the settlements. The following section describes the process of collective action based on interviews with the leaders of 180 organizations currently operating in the settlements. The paper then analyzes how CSOs contribute to human development in urban settlements by first considering their role in the provision of social services and then their broader role in the public sphere. The paper ends with a discussion of the paper's main conclusions.

\section{Methodology and data sources}

The two main sources of data used in the paper are the Civil Society Organization Survey and the Survey of Family Living Conditions and Relationship with CSOs. ${ }^{2}$ Both surveys were designed specifically for this research project and applied by our research team in seven settlements located in the southern zone of the Autonomous City of Buenos Aires (CBA): villa 21-24 (Barracas), villa 1-11-14 (Bajo Flores), villa 6 (Cildañez), villa 19 (INTA), villa 3 (Fatima), villa Piletones and the housing complex Ramon Carrillo. ${ }^{3}$ According to the 2010 National Census the combined population of these settlements is 106 thousand, approximately twothirds of the population living in informal settlements in the CBA (DGEC, 2010). ${ }^{4}$

\footnotetext{
${ }^{2}$ Mitchell (2012) provides additional information on the design of the CSO survey and Lépore (2012) on the design of the household survey.

${ }^{3}$ In some cases, the survey sampling frame included not only the specified villa but also other smaller contiguous or nearby settlements. Barracas includes the NHT-Zavaleta; Bajo Flores includes Rivadavia 1 and 2, Juan XXIII and Barrio Illia; INTA includes Bermejo and Maria Auxiliadora; Fatima, includes Calacita: Piletones includes La Esperanza; and Carrillo, Los Pinos and La Paloma.

${ }^{4}$ Unofficial estimates of the population living in the settlements close to double the official figures. For example, the population of Bajo Flores is 25,973 according to the official census (DGEC, 2010), 42,000 according to the public entity responsible for provision of public services to the settlement (the UGIS) and 60,000 according to estimates made by neighborhood leaders.
} 
The objective of the CSO survey was to register all instances of collective and organized civil society activities taking place within the boundaries of each settlement and then collect survey information on all identified organizations. The criteria used to determine whether or not to include a specific institution or action in the survey was based on the definition of the non-profit sector proposed by Salamon and Anheier (1996). According to this definition the nonprofit sector consists of entities that share the following characteristics: to be organized, private, non-profit distributing, self-governing and voluntary. We found that this definition provided the precise criteria necessary to determine case by case which groups or institutions to include in the survey and was broad enough to encompass the diverse types of organizations operating in the settlements.

The process used to identify the organizations consisted of first compiling organization directories based on government records, internet searches and initial interviews with community leaders. Many more organizations were subsequently added to the directories as organization leaders helped us to make contact with other organizations. The CSO survey field work was carried out in Bajo Flores and Barracas in 2011 and in the remaining five neighborhoods in 2012. A total of 195 organizations were identified in the seven settlements and survey data was collected on of 180 of these organizations. In 201345 additional interviews were conducted with key community leaders and public officials to gather additional information on the settlements' representative organizations and the urbanization process.

The CSO survey questionnaire was designed to collect data on the following dimensions of analysis: institutional characteristics; history; objectives; activities and programs; participants; infrastructure and equipment; human resources; sources of financing; the relationship with the state, other organizations, the private sector and networks and participation in demands against the state. Responses to open survey questions were analyzed by first identifying recurrent categories and then constructing quantitative variables.

The Survey of Family Living Conditions and Relationship with CSOs was designed to collect information on the quality of life of the families living in informal settlements and the extent to which their needs are satisfied by the goods and services provided by the public sector, markets or CSOs. Following a multidimensional concept of wellbeing consistent with the human development and capabilities approach, the survey considers both objective and 
subjective indicators in the following dimensions: demographic characteristics, international migration, housing and habitat, connectivity and accessibility, security, health, education, labor and productive activities, household economic situation, social integration and family and religious life.

The household survey was applied in two waves to a sample of 650 households living in the seven settlements. The first round of surveys was carried out during June and July, 2011 in Bajo Flores and Barracas and the second round between June and December, 2012 in the other five settlements. The irregular layout of the settlements and lack of clearly defined blocks made it impossible for us to apply habitual sample selection procedures. The sample was therefore chosen by first dividing each settlement into relatively homogeneous territorial units. Within each unit households were selected using quotas based on the characteristics of the household head. The survey respondent was female (either the female head of household or spouse), except in cases in which the household was headed by a single men. The survey results were validated by comparing estimates of more than 20 indicators with estimates based on data from the city government's Annual Household Survey (DGEyC, 2011).

In addition, the comparison of the socioeconomic characteristics of the population of the informal settlements with the rest of the city's population in the following section is based on the analysis of the micro-data from the Annual Household Survey (DGEyC, 2011).

\section{The Informal Settlements of Buenos Aires}

The informal settlements, known locally as villas, ${ }^{5}$ first emerged in the CBA in the 1930 s and 40 s as workers who migrated to urban centers to find work in the expanding industrial sector were forced to construct their own housing on unoccupied public or private lands. The villa population reached a peak of 225 thousand in 1976 before falling to only 13 thousand in 1981 as a consequence of the military dictatorship's policy of eradication of informal settlements and compulsive relocation (de la Torre, 2008).

\footnotetext{
${ }^{5}$ Villas can be defined as densely populated housing settlements composed of self-made dwellings constructed on vacant urban land, which are generally characterized by inferior access to public services, precarious structures and lacking clear delimitations of the land pertaining to each dwelling (Gallart et al, 1992: 13; translation by author).
} 
Since 1990 the rate of growth of the population in informal settlements has accelerated. According to the official population census, in 2010165 thousand people (6\% of the city's population) lived in informal settlements-fifty percent more than in 2001 and more than three times as many as in 1991 when the population in informal settlements represented only $2 \%$ of the total (DGEyC, 2010). ${ }^{6}$

The substantial growth in the population living in the settlements has contrasted sharply with the nearly stagnant population of the rest of the city. The population of the southern zone, where the majority of the villas are concentrated, grew by $9.8 \%$ between 1991 and 2010 , whereas the city's overall population contracted by $2.5 \%$. These demographic changes have led to an accentuation in the territorial concentration of poverty in the southern zone and with it the degree of residential segregation (Macció and Lépore, 2012).

The residents of the informal settlements of Buenos Aires have many of the same socio-demographic characteristics as slum residents of other global cities. The population is young $(44 \%$ is below age 18$)$, tends to live in populous households $(41 \%$ have five or more members) and headed by women (39\%). One of the most notable aspects of the villas is the large immigrant population: $61 \%$ of heads of household are foreigners (primarily from Paraguay, Bolivia and to a lesser extent Peru), compared with only $12 \%$ in the rest of the city.

Living standards in the villas are markedly inferior to those in the rest of the city. Nearly $45 \%$ of all residents suffer overcrowding (compared to only $7 \%$ in the rest of the city), one out of five lacks sanitation services (compared to less than $1 \%$ ) and $84 \%$ have irregular housing tenancy (compared with $9 \%$ ). Over $40 \%$ of the population in the informal settlements has income below the poverty line, compared with only $5 \%$ outside of the settlements.

The informal status of these territories (lack of property titles) and the social stigma associated with the term villa (Silva, 2008), contribute to social isolation and adversely affects opportunities in education, the labor market and other aspects of economic and social life. In education, repetition and drop-out rates are far higher in the settlements and the problem is especially severe at the secondary level. As a result, $20 \%$ of adolescents have not completed

\footnotetext{
${ }^{6}$ The population of the CBA is approximately 2.9 million. The Buenos Aires Metropolitan Area, which includes the CBA and the 30 suburban municipalities, has a population of 12.8 million (DGEyC, 2010) and is estimated to have more than one million people living in 680 informal settlements (Techo, 2013).
} 
primary school and $72 \%$ of youth ages 18 to 24 have not completed secondary school. The residents of the settlements also face inferior employment opportunities. Only $28 \%$ of workers living in the settlements have formal sector jobs, compared with $63 \%$ of workers in other areas of the city, and the rate of unemployment or underemployment in the settlements $(27 \%)$ doubles the rate outside of the settlements $(12 \%)$. The problems of violent crime and drug trade and consumption further reinforce the social and institutional isolation of the settlements.

\section{Civil Society Density and Structure}

Civil organizations can provide opportunities for social interaction and the forging of relations of mutual trust and social cohesion within communities (Putnam, 1994; Brehm and Rahn, 1997). Although there are considerable differences of opinion concerning the correlation between associational density and the construction of generalized trust and democratic values in society (Edwards, 2009), the evaluation of civil society density provides a relevant starting point for the analysis of the potential role of CSOs in marginalized communities.

A total of 195 organizations were identified operating in the seven settlements, or an average of 1.8 organizations per thousand residents (Table 1). This indicates that the density of the CSO sector in the settlements is somewhat below the Argentine average, but above that of some other Latin American countries. One study (GADIS et al., 2004:20), for example, indicates that Argentina has 2.9 organizations per thousand people; Chile has 2.8; Brazil, 0.7 and the United States, 4.3. Except for one outlier, all of the neighborhoods have a CSO density close to two.

Table 1 also presents two alternative measures of civil society density: the number of community members that collaborate in local organizations ${ }^{7}$ and the number of community members that participate in the activities of local organizations. ${ }^{8}$ The former provides an indicator of the degree of volunteerism, and the latter, the extent to which community members have

\footnotetext{
${ }^{7}$ This figure includes both volunteers and paid workers because usually the wages that community members receive are so low that they do not adequately compensate for the hours worked and therefore at least part of their work can be considered to be voluntary.

${ }^{8}$ The figures on the number of participants does not include participation in religious services since church leaders could not adequately estimate the number of participants, but does include participation in all other church related activities, such social programs and recreational activities.
} 
opportunities for social interaction within organized groups. According to the CSO survey, $3 \%$ of the population of the seven settlements collaborates in one of the 195 identified organizations. The percentages, however, vary widely across neighborhoods, from $4.7 \%$ and $4.6 \%$, respectively, in Barracas and Cildañez to $0.7 \%$ to $1.1 \%$, respectively, in Carrillo and Piletones. While these percentages seem low compared, for example, with the findings of the Gallup World Poll which indicates that $16 \%$ of the adult population in Argentina works as a volunteer, it is close to the percentage of adults that volunteer in social assistance organizations $(2.7 \%)$, which are precisely the types of organizations that are most prevalent in the villas (Cao et al., 2012:63).

The scale of civil society activity is markedly higher when based on the total number of people who participate in CSO activities. The participation rate based on the results of the CSO survey indicate that close to 54 thousand people living in the seven settlements (approximately half of the population) participate in the activities of a local organization. Moreover, the rate is consistently high in all of the neighborhoods. Only one of the settlements has a participation rate below $45 \%$, and two have participation rates of at least $60 \%$. While these figures may somewhat overstate the overall rate of participation (if participants tend to take part in more than one activity), it gives an idea of the magnitude of the activities offered by local organizations. Consistent with these findings, the results of the household survey indicate that in $43 \%$ of families at least one member participates in the activities of an organization located in the neighborhood.

The density of grassroots organizations ${ }^{9}$ is higher than that of outside organizations, both based on the number of organizations and the number of community members participating in organization activities. It is interesting to note, however, that relatively more community members collaborate in charitable, faith-based and other outside organizations than in grassroots ones, highlighting the importance of these types of organizations in the construction of ties between community members and people from outside of the settlements.

Approximately half of the identified organizations are social assistance providers, primarily community kitchens (Table 2). The next most important category is education, which includes daycare centers, nursery schools and charitable organizations that offer educational

\footnotetext{
${ }^{9}$ If all the people directly involved in an organization's development were living in the community at the time the organization was created, it was classified as grassroots; otherwise it was classified as an outside organization.
} 
programs for disadvantaged persons. In addition to the Catholic Church, which has either a parish or chapel in all of the settlements, a total of 16 other churches, mostly Evangelical, were identified. A total of nine research or human rights organizations operate in the seven settlements. Each neighborhood has one principal representative organization and only four out of the seven settlements have one or two additional neighborhood advocacy organizations. Other types of identified organizations include cultural and recreation organizations (such as community radios and sports clubs), political organizations, social movements, microcredit organizations and organizations to support specific groups, such as women or the disabled.

\section{Process of Collective Action}

What factors motivate people to see beyond self interest, act reciprocally and cooperate? To what extent are these actions fostered or hindered by the public sector? These are difficult questions to answer and can be addressed from many different viewpoints. This section attempts to identify some of the defining characteristics of these processes based on the results of the CSO survey, interviews conducted with key civil society and public sector actors in the settlements and selected bibliographical references. Service providing and representative organizations are considered separately.

\section{Service-providing organizations}

The oldest community kitchens and other service organizations operating today in the villas began in the mid-1980s. Organization leaders emphasize extreme poverty and poor living conditions as the principal motives for collective action. The years in which the greatest number of organizations was formed coincide with the years of most severe economic crisis. During the hyperinflation of 1989 and later during the severe economic and social crisis of 2002, when over half of the Argentine population had income below the poverty line, the residents of the settlements encountered extreme difficulties in meeting their most basic needs and depended on solidarity networks just to get by.

Many community kitchens began, for example, as reciprocal relationships in which community members contributed food to a collective pot or helped provide food to neighbors relatively worse off than themselves. Similarly, day-care centers were created when mothers 
joined together to share childcare responsibilities, enabling some mothers to work outside of the home. More recently in the face of the rising drug problem, groups of mothers have united to work toward the prevention and treatment of addictions. In all of these cases the close relationship between family, friends and neighbors facilitated cooperation.

The personal beliefs and experiences of leaders also played an important role in the initiation of collective action. A third of those surveyed stated that they were inspired by their interest in helping others and often associated these goals with their religious faith. A quarter of the leaders of grassroots organizations said that they had been motivated by a personal crisis, such as the death of a loved one or having suffered abuse earlier in their lives; a personal crisis was mentioned by the leader of only one outside organization.

The presence of a strong leader was a decisive factor in the creation of many organizations. ${ }^{10}$ According to the CSO survey, seven out of ten grassroots organizations and four out of ten outside organizations have a dominant leader who has worked in the organization since its creation. There is little evidence from the CSO survey that the large immigrant population or tensions between groups of different national origin acted as an impediment to collective action. Although some organizations were created by groups of Paraguayan or Bolivian immigrants, the majority have participants of all nationalities.

The results of the CSO survey also point to the central role of certain community actors. The Catholic parishes, for example, are not only among the oldest organizations operating in the villas and among the most important providers of social services, ${ }^{11}$ but also many organization leaders described the critical role of the parish priests in drawing organizations into the community and bridging links between grassroots organizations and contacts in the public and civil society sectors. A quarter of leaders of outside organizations mentioned contacts with the local parishes as a motive for initiating activities in the neighborhood.

Most organizations did not depend directly on public sector contacts or support for their creation. Only a quarter of grassroots organizations and one out of five leaders of outside organizations mentioned a contact with a government official when describing the process of

\footnotetext{
${ }^{10}$ This finding is consistent with the theoretical models of James (1987) and empirical evidence presented in Ostrom, (2000).

${ }^{11}$ In Barracas, where the Catholic priests have been particularly active since the mid-1990s, the results of the CSO survey indicate that one out of every five residents participates in a social program provided by the parish.
} 
development of their organization. Contacts with social movements or political parties were only mentioned in one out of ten cases. These types of contacts, however, became more important later on in enabling organizations to obtain access to financial resources and expand their activities.

In the late 1980s and early 1990s the public sector began to use networks of grassroots organizations as a means for providing social services to marginalized communities-a policy which was consistent with the government's broader economic liberalization goals (Cerruti and Grimson, 2004; Rofman, 2010). In the case of the national government, a common form of articulation with civil society has been in the administration of social plans providing direct assistance to specific vulnerable groups (Garcia Delgado and De Piero, 2002). Examples include Pro-Bienestar, which provides food and other social assistance to retired persons, the workfare program Plan Trabajar introduced in 1999 and the massive program Plan Jefes y Jefas adopted following the 2002 crisis to provide supplementary income to unemployed heads of household. Many beneficiaries of the latter two programs completed the plan's required work activities in CSOs, thereby providing organizations with what amounted to paid employees.

The city government introduced in 1986 the Program for Support of Community Organizations with the expressed goals of strengthening organizations in poor communities and decentralizing the provision of social services (Bonaldi, 2006). This program continuously expanded over the following two decades and today provides food rations and material and technical assistance to 320 organizations that provide community kitchens; daycare centers and educational, cultural and recreational activities in the settlements. ${ }^{12}$

The access to a regular source of financing from the public sector enabled many grassroots organizations to become formal associations and offer new complementary social services such as afterschool or adult literacy programs, many of which later obtained public support. These arrangements of coproduction with CSOs enabled the government to placate the needs of residents and form alliances with community leaders in difficult to access and politically strategic neighborhoods.

\footnotetext{
12 http://www.buenosaires.gob.ar/areas/des_social/politica alimentaria/grupos_com.php?menu id=15509, (consulted March 12, 2014).
} 
Representative organizations

Quite different from the case of the grassroots organizations oriented toward the provision of social services, the settlements' representative organizations have passed through different phases, some periods in which residents unified themselves around collective demands and other periods marked by slower progress. According to a number of accounts, the first neighborhood representative organizations were created in the second half of the 1950s (Cravino, 1998). Their primary demands focused initially on defending the right to live on occupied lands and gaining access to basic public services, such as water and electricity. In 1958 the first second tier organization was created, the Federation of Villas and Needy Neighborhoods, which along with other subsequently created federations, such as the National Villero Liberation Front and the Peronist Villero Movement, enabled the neighborhood commissions of individual settlements to make collective demands from within a broader organizational structure (Cravino, 1998).

The policy of forced eradication of the settlements introduced by the military government that assumed power in 1976 had a decisive effect on the process of development of these organizations. In interviews, community leaders described how the military government had forcibly suppressed community organization activities. Some leaders, however, spoke of how the forced eradication policy had helped to unite community members and instill a common neighborhood identity, at least among the residents that managed to resist eviction. One leader expressed "The neighborhood was destroyed. The bulldozers came and tore down everything and then we organized. We put together the political organization of the neighborhood, the creation of the villero movement. It was the beginning." ${ }^{13}$

Another defining characteristic of the process has been the progressive use of judicial and legislative processes as a means for attaining formal recognition of the legitimate rights of representative organizations to participate in the urbanization processes. The municipal Law 148, sanctioned in 1998, was an important milestone as it conferred the responsibility for the diagnosis, planning and control of public policies related to the settlements to a coordinating

\footnotetext{
${ }^{13}$ From an interview with an organization leader in Cildañez conducted on May 28th, 2014.
} 
commission, comprised of the city government, villa movements and neighborhood representative organizations.

The municipal Law 403, which applies specifically to Bajo Flores, goes even further as it calls for the participation of the community in all stages of the urbanization process and recognizes the settlement's representative body as the valid and legitimate neighborhood representative. The enactment of this law led to the replacement of the existing neighborhood council (junta vecinal), which had a vertical organizational structure, with a horizontallystructured body of delegates (cuerpo de delegados), consisting of 59 block representatives.

Effective participation in the urbanization process, however, has lagged far behind the advancement in the creation of a normative framework. In 2008 , following numerous cases of non-compliance with the urbanization law, a city legislative representative presented a judicial action that denounced the failure of the city government to create the coordinating commission and demanded the designation of a court appointed mediator responsible for the organization of elections for delegates of the representative organizations in each neighborhood. ${ }^{14} \mathrm{~A}$ subsequent judicial order obliged the government to undertake electoral censuses and call elections for neighborhood representatives.

Elections were subsequently carried out in all of the settlements included in our sample, except in Cildañez. ${ }^{15}$ Organization leaders, however, have denounced irregularities in the election processes in several of the settlements. In Carrillo, for example, opposing community leaders claim that the elections were rigged to benefit an organization loyal to the city government. As a result, many settlements lack a representative body broadly considered to be legitimate.

There is, therefore, a legal framework that establishes the right and responsibility of neighborhood councils to act in representation of the residents of the informal settlements. The following section, however, will consider to what extent these organizations provide effective forums for voicing the collective demands of the community.

\footnotetext{
${ }^{14}$ The legislation was presented by Facundo Di Filippo, president of the Housing Commission of the CBA Legislature.

${ }^{15}$ According to community leaders, the last elections were carried out in Cildañez in 2002. The mandates of the neighborhood commission's representatives have expired leaving a vacuum of power and lack of legitimate representation.
} 


\section{Service Providers or Forces for Change}

There is an ongoing debate concerning the role of civil society in the modern world (Edwards, 2009). Some authors emphasize the role of civil society in substituting or collaborating with the state in the provision of social services (Salamon and Anheier, 1996), whereas others underscore its role as force for change, a means for building and deepening democracy though active deliberation and participation in the public sphere (Avritzer, 2002). This section will analyze how each of these roles of civil society can contribute to human development in informal settlements.

\section{Provision of Social Services}

Food assistance is by far the most important type of social service offered by the organizations operating in the settlements (Table 3). According to the CSO survey, 97 food assistance programs provide a total of 190 thousand rations of food per week to more than 22 thousand people. The household survey indicates that in $32 \%$ of households at least one member had attended a community kitchen during the month prior to the survey, and in $71 \%$ of these cases they had been receiving food rations for more than one year. Most food assistance programs provide food rations to people of all ages and it is common for a family member to take home enough rations to feed the entire family. Nine out of ten food assistance programs receive public sector financing and most programs receive food rations delivered daily by the city government.

While two-thirds of the organizations that provide food assistance responded that they could not satisfy all of the demand, there is no strong evidence indicating that there are extremely needy families living in the settlements that are unable to access food from one of these programs. Moreover, $30 \%$ of the families that currently attend food assistance programs have been doing so for at least five years and, what is even more surprising, is that long-term attendance of community kitchens is higher among families classified as non-poor (50\%) than among poor families (24\%).

Although the principal focus of the service-providing organizations in the settlements has been the satisfaction of basic needs, over time most organizations have introduced other types of social promotion activities such as educational, recreational, cultural, job-training or 
health service programs. Within education, the most prevalent programs are the afterschool tutoring programs for children and youths, daycare and nursery schools and adult literacy or primary school completion programs. Except for the afterschool programs, which often consist of informal activities guided by volunteers, the majority of the educational programs receive public support. For example, the city government has made efforts to improve access to childcare services through a program that sets up early childhood centers ${ }^{16}$ in local organizations. Although the program provides high quality services and has enabled the government to expand the supply of services without having to go through the usual channels necessary to create formal education institutions, the demand for daycare services still greatly exceeds the supply.

Sports programs include football, hockey, rugby and even cricket for children and youths. Cultural programs include music, theater, photography, circus and dance. Many sports and cultural programs are used as a means for engaging youth and teaching values. Around forty percent of these programs receive public sector financing.

The CSO survey registered information on a total of 62 employment programs, which offer job training in electricity, carpentry, auto mechanics and computers, as well as microcredit programs. In the case of the employment programs, attracting and retaining participants is relatively more of a problem than the inability to satisfy the demand. Although close to $20 \%$ of families are highly dissatisfied with their employment situation, in only $6 \%$ a family member had participated in a job training program in a CSO during the previous last year. It is likely that many laborers living in the settlements perceive that additional training will not increase their job opportunities or are too busy working to take time out for job training. Four out of ten employment programs receive financing from the public sector.

Health-related activities include workshops in topics such as reproductive health, oral hygiene and nutrition; a limited number of health services programs; and drug treatment programs to address the growing problem of drug addictions. While only a quarter of these programs receive public financing, in many cases organizations articulate directly with doctors and social workers from the local primary health center.

\footnotetext{
${ }^{16}$ Centros de Primera Infancia.

http://www.buenosaires.gob.ar/areas/des_social/fortal_soc_civil/centros_primerainfancia.php?menu_id=31342
} 
Other types CSO programs include legal advice, support groups for women, addiction prevention programs, community development programs (mostly focused on advocacy, rather than on service provision) and a limited number of homes for youths or the elderly.

The comparison between the dimensions in which families are least satisfied and the services provided by CSOs (Figure 1) suggests that there is a low level of correspondence between perceived needs and the activities carried out by local organizations. Food, education and health are the areas in which families obtain the greatest amount of services from CSOs and also the dimensions in which the lowest percentage of families responded that they are highly dissatisfied. This result may be, in part, an indication of the effectiveness of the social service programs provided by CSOs. It is likely that food is the dimension in which families are the most satisfied precisely because of the widespread access to food from neighborhood community kitchens. The low level of dissatisfaction in these dimensions, however, also is likely related to the fact that poor, marginalized families tend to naturalize situations of hardship and have lower expectations regarding the quality of schools or medical care.

The dimensions in which households are least satisfied are security and housing. Insecurity, in fact, is one of the principal concerns of the whole Argentine population today. ${ }^{17}$ The residents of villas are often viewed as the culprits of crime, but the household survey results show that they are some of the principal victims of insecurity. In $47 \%$ of households some member had been a victim of a violent crime during the previous year. Nearly $40 \%$ of household survey respondents stated that they do not feel at all safe in the neighborhood and $21 \%$ do not feel safe even within their homes. The primary complaints with regard to housing are the poor quality of construction, overcrowding, poor ventilation, humidity and low quality or lack of access to public services. Although families are highly dissatisfied with both security and housing, fewer than $5 \%$ have received help from organizations in these areas. The CSO survey identified almost no cases of social services in housing (such as housing credit or housing construction or improvement programs) or security (such as programs to provide safe corridors to bus routes). At the same time, many after-school, recreational activities and cultural programs

\footnotetext{
${ }^{17}$ A recent survey indicates that the principal problems perceived by Argentine families are drug-trafficking (83\%), followed by insecurity (79\%). See "El narcotráfico ya encabeza las preocupaciones de la sociedad" La Nación newspaper, March 9, 2014. http://www.lanacion.com.ar/1496430-la-inseguridad-es-la-mayor-preocupacion
} 
may help to reduce crime by keeping children and youths off of the street and preventing substance abuse.

Although the mix of factors that contribute to the "supply" and "demand" for social services is complex, these findings lead one to question how relations of coproduction between civil society and the state-arrangements established in many cases more than twenty years ago-affect the capacity of organizations to establish their own priorities and gear their activities toward the most pressing demands of the population. To what extent do relations of coproduction create vested interests that make it more difficult for organizations to alter their focus when needs change? How can organizations be strengthened so as to enable them to better respond to the perceived needs of members of the community?

Organizations depend almost exclusively on the public sector for economic resources (Figure 2). Eighty percent of grassroots organizations receive financing from the city or the national government for at least one of their programs. All other sources of financing for grassroots organizations are very limited: only $15 \%$ obtain resources from individuals, $9 \%$ from the private sector, $6 \%$ from fundraising activities and $5 \%$ from religious entities. Half of all programs administered by grassroots organizations have only one source of financing. While the sources of financing of outside organizations are relatively more diversified, still nearly $60 \%$ obtain funding from the public sector.

In most cases, CSOs are only responsible for program administration, but have little influence on the design of social service programs and policies, a result that is consistent with the findings of other studies (Garcia Delgado and De Piero, 2002: 76). Some organization representatives complained about the lack of preventive action and long term planning on the part of the state and the lack of transparency in the allocation of resources. In some cases, organization leaders perceive the need to have political ties in order to obtain government funds. The discretional allocation of resources to organizations is a source of conflict between organizations and may limit their ability to unite around common goals.

Forces for change

While the representative organizations' overarching goal of transforming the settlements into formal neighborhoods has remained the same, specific demands have evolved over time as the communities have advanced in the urbanization process. Collective goals have gone from 
gaining access to basic public services (water, sewerage and electricity); to obtaining paved roads, streetlights and community health centers; to more recent demands for improvements in the quality of public services or for access to ambulance services. These advances provide evidence of the effectiveness of actions of residents of marginalized communities to work collectively toward the advancement of common goals. One community leader expressed, "The things that have been done are because the people organize themselves. The changes were gradual and always depended on the capacity for organization of the neighborhood and the political orientation of the city's government." 18

Street blockages, occupation of public buildings and other forms of mobilization have been the methods most frequently used to voice the concerns of the population. Many CSO leaders stated that this was their only means for making the government listen to their demands. Although violent protests are still common (and often very effective), representative organizations increasingly express demands through the preparation of formal petitions, a tendency identified by other authors (Giurleo, 2012). Organizations often partner with formal research, human rights or development organizations, such as the Civil Association for Equality and Justice (ACIJ) and the Center for Legal and Social Studies (CELS), which aid in the presentation of judicial requests.

Some civil society leaders also emphasized that neighborhood groups had succeeded in gaining access to public services, not only through protests or demands against the state, but also because the neighbors had worked together to install water lines, extend electrical cables or improve their housing constructions. An organization leader in Piletones explained how the collaboration between neighbors in these types of projects had helped to unify the community. ${ }^{19}$

There have also been some cases of effective articulation between civil society and public sector entities to solve specific problems facing the settlements. A relevant example is the Working Group on Urban Hygiene formed to address the problem of trash collection, which is comprised of public officials from the city's Ministry of Environment and Public Spaces, grassroots organizations and several research/human rights organizations, including the Civil Association for Equality and Justice (ACIJ), the City Foundation and the Foundation for

\footnotetext{
${ }^{18}$ From an interview with a community leader in Bajo Flores conducted on June 11, 2013.

${ }^{19}$ Based on an interview with an organization leader in Piletones conducted on July 12, 2013.
} 
Democratic Change. ${ }^{20}$ The group organizes regular public meetings in each villa and seeks to find solutions that take into account the specific problems and characteristics of each neighborhood.

Several organization leaders expressed satisfaction with the progress of regularization of the settlements, perceiving the current urbanization plan (the Program to Consolidate, Integrate and Transform Villas and Transitory Housing Units) ${ }^{21}$ to be the culmination of decades of community action. Others, however, expressed frustration over the slow pace of urbanization, the deterioration in the quality of public services (due to the deficient capacity of the infrastructure, precarious individual connections and population growth) and worsening environmental problems. The urbanization process itself has also brought new challenges. For example, the opening up of streets has meant that some families have had to be moved out of the neighborhood and some residents are concerned that if the neighborhood is formalized it will become too expensive for them to live there.

Neighborhood council representatives spoke of different factors that limit the capacity of residents to work collectively toward the advancement of long term goals. Some recognized that the representative organizations' ineffectiveness is due to the lack of internal cohesion ("everyone trying to get water for their own well," as one representative put it) and vested interests between public officials and people in positions of power in the neighborhood. ${ }^{22}$

Conflicts between organizations, and especially between different groups vying for control of the neighborhood councils, is another problem frequently mentioned by civil society leaders. Some leaders denounced the lack of transparency in the allocation of lucrative public sector contracts to government-allied organizations for the provision of trash collection, electricity maintenance and other neighborhood public services. They contend that both the city and the national governments use clientelistic networks as a means for channeling resources

\footnotetext{
${ }^{20}$ http://www.cambiodemocratico.org/?proyectos=mesa-de-higiene-urbana-en-villas (consulted March 26, 2014).

${ }^{21}$ http://www.buenosaires.gob.ar/areas/planeamiento obras/vivienda/programas.php?menu id=21512 (consulted March $25,2014)$.

${ }^{22}$ Based on an interview with a delegate of the neighborhood representative organization in Barracas conducted on March 30, 2011.
} 
into the community in exchange for political support. ${ }^{23}$ One community leader asserted, "The government always tries to have one or two brokers (punteros) to channel things, to demonstrate that they are doing something, and then later you realize that it has all been negotiated". ${ }^{24}$ Some delegates even claim that the city government intentionally divides up groups and organizations in order to keep the community from making unified petitions.

The results of the CSO survey indicate that organizations tend to prioritize organizationspecific over collective goals. While nearly half of all organizations in the settlements (including those focused on the provision of social services) responded that they had participated in a protest or demand against the state during the previous year, in seven out of ten cases the objective was to obtain additional economic resources for their own organization or public sector jobs or subsidies for their members; in only three out of ten cases the organization sought to advance broader, community-wide goals.

Irregularities in election processes, conflicts between organizations and lack of transparency in the allocation of government resources all contribute to lowering confidence in civil society and weakening the capacity to garner community support for collective initiatives. According to the household survey, $41 \%$ of respondents trust CSOs, $33 \%$ trust CSO leaders and only $23 \%$ trust the delegates of representative organizations. And, while residents participate actively in the social service activities offered by CSOs, the level of broader civic participation is quite low. Only $6 \%$ of household survey respondents said that they participate in neighborhood assemblies and $3 \%$ participate in a political party or a social movement.

Insecurity and neighborhood conflicts between rival gangs, nationalities and sectors of the villas also act as obstacles to participation in the public sphere. Both CSO leaders and household survey respondents explained that violence causes some families to isolate themselves socially. There is also evidence that out of fear some residents avoid participating in collective demands in sensitive areas such as insecurity or drug trade. An organization leader in Bajo Flores explained, for example, that she had received threats from criminal groups after she had actively participated in public assemblies to fight neighborhood crime. ${ }^{25}$

\footnotetext{
${ }^{23}$ There is a broad literature on clientelism and the cooption of grassroots organizations in marginalized neighborhoods. See, for example, Auyero (2001) and Espósito Guevara (2008).

${ }^{24}$ Based on an interview with a community leader in Bajo Flores conducted on June 4, 2013.

${ }^{25}$ Based on an interview with an organization leader in Bajo Flores conducted on June 16, 2011.
} 
The lack of effectiveness of the settlements' neighborhood councils also reflects the failure of government to provide opportunities for popular participation in the public decisionmaking process. Despite the existence of a legal framework guaranteeing representative organizations the right to participate (through the coordinating commission) in the diagnosis, planning and control of public policies related to the settlements, many delegates complain that the government excludes the organizations from the urbanization process. Although some wellconnected organizations leaders stated in interviews that they had contributed to the design of public policies and programs, these consultations do not occur in a plural context, but rather tend to be based on personal relationships with public officials. The lack of openness to civil participation in public deliberation may be the characteristic that most clearly distinguishes the City of Buenos Aires from some notable experiences in other Latin American countries in developing new forms of participatory democracy to address the problems associated with growing urban marginality (Ziccardi, 2008; Novy and Leubolt, 2005; Gurza Lavalle, et al. 2005).

\section{Conclusions}

In contrast with some theoretical premises concerning the erosion of networks of institutions in marginalized communities, this paper presents evidence of a dense network of civil society organizations operating in the informal settlements of the City of Buenos Aires. Most grassroots organizations emerged during periods of severe economic crisis out of the networks of solidarity and reciprocal collaboration among community members. The principal role of these organizations is the provision of social services. Although many organizations began as community kitchens, they have increasingly diversified their activities to include educational, recreational, cultural, health and job training programs and, at the same time, new social movements, religious and development organizations from outside the community have initiated activities in these neighborhoods. The programs provided by these organizations both help to meet the unsatisfied demand for social services (for example, daycare services) and compensate for the inferior quality of public services in the city' deteriorated southern zone (for example, in education and health).

Although the public sector played only a limited role in the creation of local organizations, today most CSOs depend almost exclusively on the state for financial resources 
and many organizations focus their activities on the administration of programs designed and financed by the public sector. These relationships of coproduction have enable both the city and national governments to satisfy basic needs in the settlements and to build alliances with community leaders in difficult to access and politically strategic neighborhoods. A relevant question is how the structural dependence of CSOs on the public sector, combined with the lack of transparency in the allocation of public resources, limit the capacity of organizations to alter programs in response to changing needs or reduce the advocacy role of civil society in defending collective interests before the state.

Each settlement also has one dominant representative organization that acts as the principal vehicle through which community members convey to government their collective demands for equal access to public services and their rights to full integration of their neighborhoods into the city. These organizations whose origins date back to the 1950s have been instrumental in the gradual transformation of land occupations into neighborhoods made up of buildings made with construction materials and which have access to most basic public services. The inequalities that remain, however, are still enormous. Residents lack formal titles to their properties, have access to inferior quality public services and face many complex problems, including neighborhood violence, isolation and discrimination.

The representative organizations of many of the settlements lack broad legitimacy due to irregularities in the elections of delegates. Moreover, lack of internal cohesion, conflicts between local organizations and lack of transparency in the allocation of government resources all reduce the overall confidence in civil society and make it more difficult to unite the community around collective goals. And, even in cases in which the representative organizations enjoy greater legitimacy, the opportunities for the participation of civil society in the public decisionmaking process are extremely limited, despite the fact that a legal framework exists which should guarantee this right.

In conclusion, it is important to recognize that the multiplicity of CSO activities focused on the satisfaction of basic needs has a limited effect on removing the segregation in the access to social opportunities that reproduce economic and social marginality. True empowerment of community members to collectively work toward shared objectives requires the strengthening of 
representative organizations so that the inhabitants of the informal settlements can act as a unified force for change. 
Table 1: Civil Society Sector Density

\begin{tabular}{|c|c|c|c|c|c|c|c|}
\hline & \multirow[b]{2}{*}{$\begin{array}{c}\text { Total } \\
\text { Population }\end{array}$} & \multicolumn{2}{|c|}{ Number of CSOs } & \multicolumn{2}{|c|}{$\begin{array}{l}\text { Residents that } \\
\text { colaborate in CSOs }\end{array}$} & \multicolumn{2}{|c|}{$\begin{array}{l}\text { Participants in } \\
\text { CSO activities }\end{array}$} \\
\hline & & Total & $\begin{array}{l}\text { per '000 } \\
\text { people }\end{array}$ & Total & $\begin{array}{c}\% \\
\text { population }\end{array}$ & Total $^{a}$ & $\%$ population \\
\hline Barracas & 32.688 & 63 & 1,9 & 1.524 & 4,7 & 19675 & 60,2 \\
\hline Bajo Flores & 25.973 & 43 & 1,7 & 733 & 2,8 & 11908 & 45,8 \\
\hline Carrillo & 16.500 & 18 & 1,1 & 109 & 0,7 & 4780 & 29,0 \\
\hline Fatima & 10.643 & 28 & 2,6 & 178 & 1,7 & 4808 & 45,2 \\
\hline Cildañez & 9.511 & 21 & 2,2 & 437 & 4,6 & 5078 & 53,4 \\
\hline Piletones & 6.718 & 12 & 1,8 & 73 & 1,1 & 3210 & 47,8 \\
\hline INTA & 4.010 & 10 & 2,5 & 112 & 2,8 & 3052 & 76,1 \\
\hline Grassroots CSOs & 106.043 & 118 & 1,1 & 1.443 & 1,4 & 34095 & 32,2 \\
\hline Outside CSOs & 106.043 & 79 & 0,7 & 1.723 & 1,6 & 19817 & 18,7 \\
\hline Total & 106.043 & 195 & 1,8 & 3.166 & 3,0 & 53912 & 50,8 \\
\hline
\end{tabular}

Source: CSO Survey 2011-2012. Population figures from DGEyC (2010).

a. Excludes participation in religious services. 
Table 2: Number of organizations by type

\begin{tabular}{|l|c|c|c|c|c|c|c|c|}
\hline Category $^{\text {a }}$ & Barracas & $\begin{array}{c}\text { Bajo } \\
\text { Flores }\end{array}$ & Carrillo & Fatima & Cildañez & Piletones & INTA & Total \\
\hline Social assistance & 29 & 27 & 8 & 12 & 5 & 3 & 6 & 90 \\
\hline Education & 11 & 5 & 2 & 3 & 3 & 3 & 0 & 27 \\
\hline Religious & 7 & 3 & 1 & 4 & 5 & 2 & 1 & 23 \\
\hline Cultural, Recreation \& Sports & 3 & 2 & 2 & 2 & 5 & 1 & 2 & 17 \\
\hline Neighborhood & 3 & 1 & 2 & 2 & 2 & 1 & 1 & 12 \\
\hline Research \& Human rights & 6 & 2 & 1 & 0 & 0 & 0 & 0 & 9 \\
\hline Political \& Social movements & 4 & 2 & 0 & 2 & 0 & 1 & 0 & 9 \\
\hline Employment \& Productive & 0 & 1 & 1 & 1 & 0 & 1 & 0 & 4 \\
\hline Other & 0 & 0 & 1 & 2 & 1 & 0 & 0 & 4 \\
\hline Total & & & & & & & & 195 \\
\hline
\end{tabular}

Source: CSO survey, 2011-2012.

a. Organizations were classified based on the purpose for which the organization was created. 
Table 3: Social Service Provision by Category

\begin{tabular}{|c|c|c|c|c|c|}
\hline Category & $\begin{array}{l}\text { 1. Number } \\
\text { of } \\
\text { Programs }\end{array}$ & $\begin{array}{c}\text { 2. Number } \\
\text { of } \\
\text { Participants }\end{array}$ & $\begin{array}{l}\text { 3. Unsatisfied } \\
\text { demand } \\
(\%)\end{array}$ & $\begin{array}{l}\text { 4. Difficulty } \\
\text { in attracting } \\
\text { or retaining } \\
\text { participants } \\
\text { (\%) }\end{array}$ & $\begin{array}{l}\text { 5. Receive } \\
\text { public } \\
\text { financing } \\
(\%)\end{array}$ \\
\hline Food & 97 & 22,591 & 64 & 4 & 92 \\
\hline Education & 105 & 6780 & 40 & 13 & 50 \\
\hline After-school program & 61 & 4,115 & 26 & 11 & 28 \\
\hline Daycare & 18 & 1,279 & 83 & 6 & 78 \\
\hline Adult literacy & 18 & 578 & 17 & 28 & 78 \\
\hline Nursery school & 6 & 643 & 100 & 0 & 100 \\
\hline Secondary school & 2 & 165 & 100 & 50 & 100 \\
\hline Recreation, sports \& recreation & 104 & 5966 & 14 & 8 & 43 \\
\hline Recreation and sports & 57 & 4,592 & 17 & 5 & 45 \\
\hline Cultural programs & 47 & 1,374 & 9 & 9 & 42 \\
\hline Employment \& productive & 62 & 2308 & 24 & 23 & 39 \\
\hline Job training & 45 & 1,426 & 22 & 20 & 36 \\
\hline Other productive and employment & 17 & 882 & 29 & 29 & 47 \\
\hline Health & 24 & 2,123 & 21 & 13 & 25 \\
\hline Health training & 11 & 600 & 27 & 9 & 9 \\
\hline Health services & 7 & 1,330 & 29 & 0 & 43 \\
\hline Treatment of addictions & 6 & 193 & 0 & 33 & 33 \\
\hline Community development/Housing & 18 & a & $a$ & $a$ & $a$ \\
\hline Legal advice & 12 & 2,732 & 0 & 0 & 38 \\
\hline Help to women & 12 & 400 & 8 & 8 & 17 \\
\hline Adiction prevention & 7 & 1,775 & 29 & 14 & 43 \\
\hline Homes & 5 & 88 & 60 & 0 & 20 \\
\hline
\end{tabular}

Source: CSO survey 2011-2012.

a. Most programs benefit the whole neighborhood or at least one sector. 
Figure 1: Help from CSO and Dissatisfaction with each Dimension

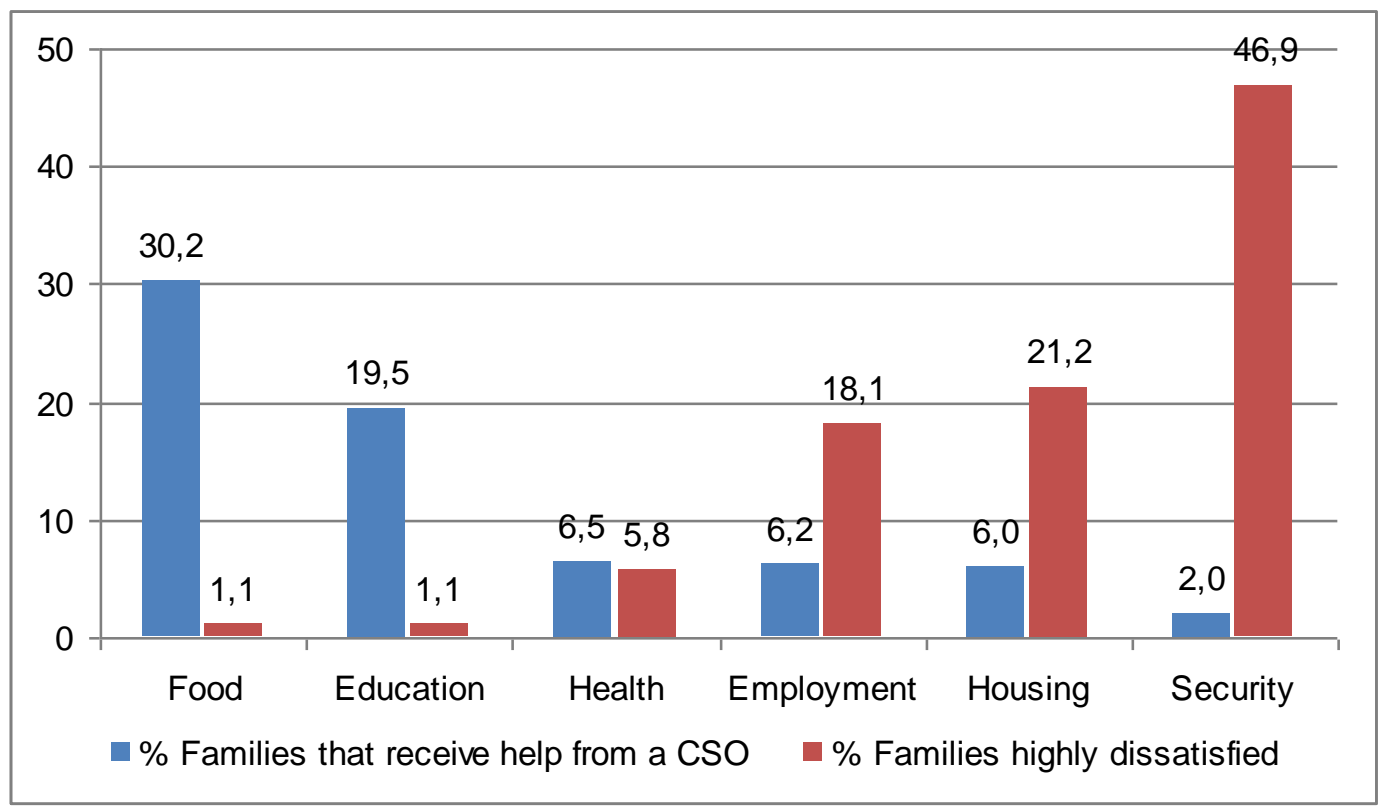

Source: Household Survey, 2011-2012. 
Figure 2: Sources of CSO Financing (\%)

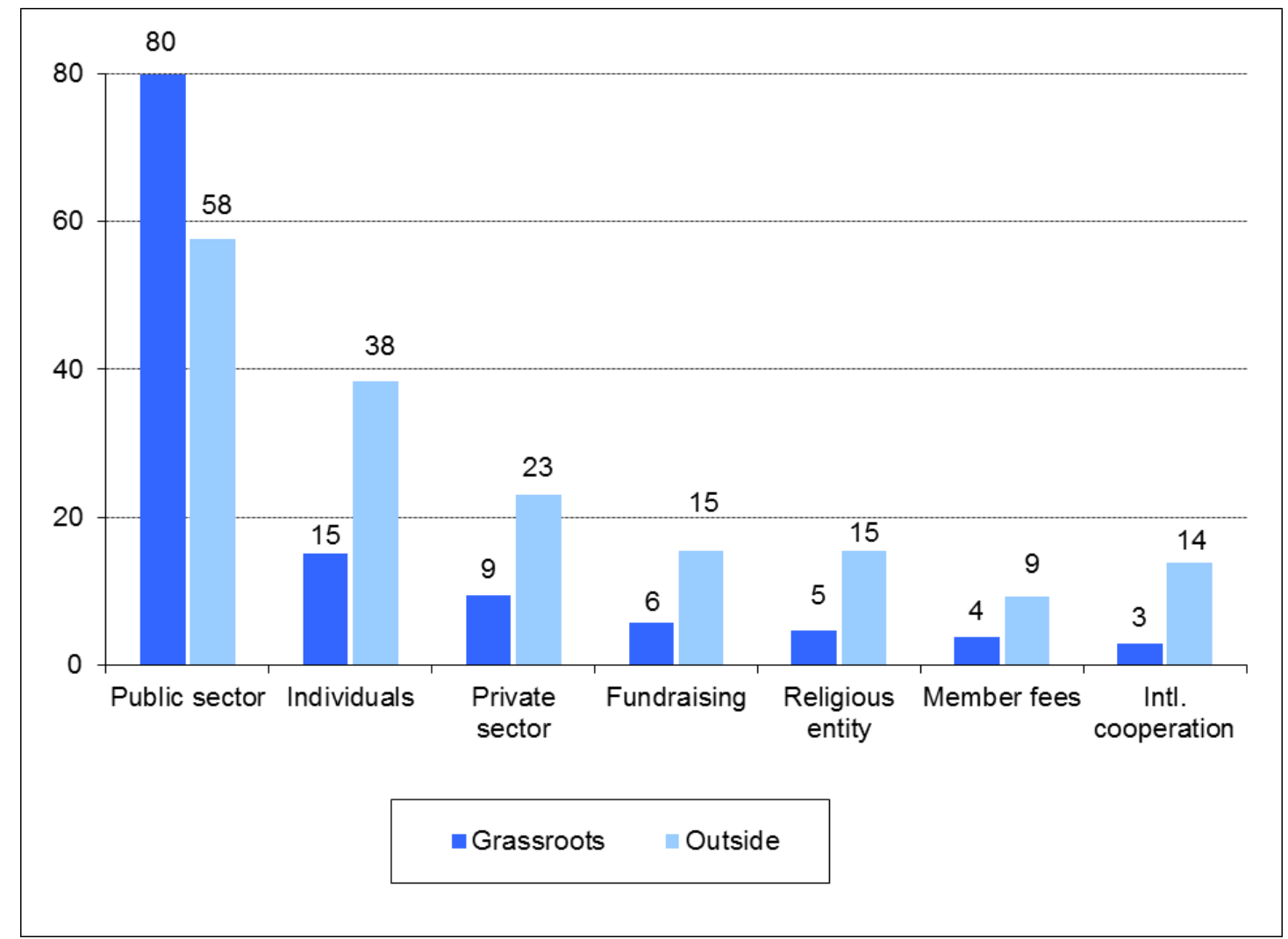

Source: CSO survey 2011-2012. 


\section{References}

Alkire, S. and Deneulin, S. (2010) The Human Development and Capability Approach in Deneulin, S. (ed.) Introduction to the Human Development and Capability Approach, Earthscan, London.

Auyero, J. (2001) Las políticas de los pobres. Las prácticas clientelares del peronismo, Manantial, Buenos Aires.

Avritzer, L. (2002) Democracy and Public Space in Latin America Princeton University Press, Princeton, NJ.

Bonaldi, P. (2006) Análisis de la implementación del Programa de Apoyo a Grupos Comunitarios, Cuadernos de CLASPO-Argentina, 12, July 2006.

Brehm, J. and Rahn, W. (1997) Individual level evidence for the causes and consequences of social capital. American Journal of Political Science, 41: 999-1023.

Campfens, H. (1997) International review of community development in H. Campfens (ed.) Community Development Around the World. Practice, Theory, Research, Training, Pact Publications, New York.

Cao, C., Cecconi, E. and Balian, B. (2011) La Sociedad Civil Argentina en el Bicentenario. Índice CIVICUS de la Sociedad Civil Argentina (2008-2010), GADIS, Buenos Aires.

Cerrutti, M. and Grimson, A. (2004) Buenos Aires, neoliberalismo y después. Cambios socioeconómicos y respuestas populares Cuadernos del IDES, October 2004.

CIVICUS, GADIS (2004) La Sociedad Civil Por Dentro: Tiempo de Crisis, Tiempo de Oportunidades. Índice CIVICUS de la Sociedad Civil Argentina, Buenos Aires.

Cravino, M. C. (1998) Las organizaciones villeras en la Capital Federal entre 1989-1996. Entre la autonomía y el clientelismo, 1er Congreso Virtual de Antropología y Arqueología.

de la Torre, L. (2008) Buenos Aires: del conventillo a la miseria (1869-1989), Educa, Buenos Aires.

Dirección General de Estadística y Censos (2011) Encuesta Anual de Hogares 2011 Ciudad de Buenos Aires Síntesis metodológica, Gobierno de la Ciudad de Buenos Aires, Buenos Aires.

Dirección General de Estadística y Censos (2010) Resultados Previsionales del Censo Nacional de Población, Hogares y Vivienda 2010 en la Ciudad de Buenos Aires, Gobierno de la Ciudad de Buenos Aires, Buenos Aires.

Donaghy, M. (2013) Civil Society and Participatory Governance: Municipal Councils and Social Housing Programs in Brazil, Routledge, New York.

Edwards, M. (2009) Civil Society Polity Press, Malden, MA.

Ekirapa, A., Mgomella, G., and Kyobutungi, C. (2012) Civil society organizations: Capacity to address the needs of the urban poor in Nairobi Journal of Public Health Policy, 33, 4, November 2012, pp. 404-422.

Espósito Guevara, C. A. (2008) Exclusión política, des-ciudadanización y profundización de la pobreza urbana en Bolivia in Ziccardi, A. (Comp.) Procesos de urbanización de la pobreza y nuevas formas de exclusión social. CLACSO, Buenos Aires. 
GADIS, PNUD and BID (2004) Índice de Desarrollo de la Sociedad Civil de Argentina. Total País, Edilab, Buenos Aires.

Gallart, M. A., Moreno, M., Cerrutti, M. and Suarez, A. L. (1992) Las trabajadoras de villas: familia, educación y trabajo Cuaderno del CENEP, 46.

Garcia Delgado, D. and De Piero, S. (2002) Articulación y relación Estado-Organizaciones de la sociedad civil. Modelos y prácticas en la Argentina de las reformas de segunda generación, FLACSO, Buenos Aires.

Giurleo, P. M. (2012).La judicialización de las demandas villeras. Justicia, Política y Acción Colectiva en las villas de Buenos Aires. Tesis de Maestría en Ciencias Sociales. Universidad Nacional de General Sarmiento (UNGS), Instituto de Desarrollo Económico y Social (IDES), Los Polvorines, Argentina.

Gurza-Lavalle, A. Acharya, A.and Houtzager, P. (2005) Beyond Comparative Anecdotalism: Lessons on Civil Society and Participation from Sao Paolo, Brazil World Development, 33, 6, 951-964.

James, E. (1987) "The Non-profit Sector in Comparative Perspective" in W. W. Powell (ed.) The Nonprofit Perspective: A Research Handbook. New Haven, Conn., Yale: University Press.

Lépore, S. (2012) Sociabilidad e integración social en las villas de Bajo Flores y de Barracas in Lépore, E., Lépore, S., Mitchell, A., Macció, J. and Rivero, E. Capacidades de desarrollo y sociedad civil en las villas de la ciudad, Educa, Buenos Aires, 205-268.

Macció, J. and Lépore, E. (2012) Las villas en la Ciudad de Buenos Aires. Fragmentación espacial y segmentación de las condiciones sociales de vida in Lépore, E., Lépore, S., Mitchell, A., Macció, J. and Rivero, E. Capacidades de desarrollo y sociedad civil en las villas de la ciudad, Educa, Buenos Aires, 43-114.

Magaloni, B., Diaz-Cayeros, A. and Estevez, F. Clientelism and portfolio diversification: a model of electoral investment with applications to Mexico in Kitschelt $\mathrm{H}$. and Wilkinson, S. (eds.) Patrons, Clients and Policies. Patterns of Democratic Accountability and Political Competition Cambridge University Press, Cambridge, UK.

Meyer, M. and Hyde, C. (2004) Too Much of a "Good" Thing? Insular Neighborhood Associations, Nonreciprocal Civility and the Promotion of Civic Health Nonprofit and Voluntary Sector Quarterly, Supplement, 33, 3, September 2004, 77S-96S.

Mitchell, A. (2012) Las organizaciones de la sociedad civil en las villas de Bajo Flores y Barracas in Lépore, E., Lépore, S., Mitchell, A., Macció, J. and Rivero, E. Capacidades de desarrollo y sociedad civil en las villas de la ciudad, Educa, Buenos Aires: 115-187.

Molenaers, N. (2006) Associational life and local development in two Nicaraguan villages CEPAL Review V. 90, December 2006.

Novy, A. and Leubolt, B. (2005) Participatory Budgeting in Porto Alegre: Social Innovation and the Dialectical Relationship of State and Civil Society Urban Studies, 42, 11, 2023-2036.

Nussbaum, M. (2006) Poverty and Human Functionings: Capabilities as Fundamental Entitlements in Grusky, D. and Kanbur, R. (eds.) Poverty and Inequality, Stanford University Press, Stanford, CA.

Ostrom, E. (2000) Collective Action and the Evolution of Social Norms Journal of Economic Perspectives, 14, 3, Summer 2000.

Pereira Leite, M. (2008) Pobreza y exclusión en las favelas de Río de Janeiro in Ziccardi, A. (comp.) Procesos de urbanización de la pobreza y nuevas formas de exclusión social. CLACSO, Buenos Aires. 
Putnam, R.D., Leonardi, R. and Nanetti, R. (1994) Making Democracy Work: Civil Traditions in Modern Italy Princton University Press, Princeton, NJ.

Rofman, A., Gonzalez Carvajal, M. and Anzoategui, M. (2010) Organizaciones sociales y Estado en el conurbano bonaerense: un estudio de las formas de interacción in Sociedad y territorio en el Conurbano Bonaerense, Universidad Nacional de General Sarmiento, Los Polvorines, Argentina, 153-216.

Salamon, L.M. and Anheier, H. (1996) The Emerging Non-Profit Sector, Manchester University Press, Manchester.

Sen, A. (1984) The Living Standard Oxford Economic Papers, New Series, 36, Supplement: Economic Theory and Hicksian Themes, November 1984, 74-90.

Sen, A. (1985) Well-Being, Agency and Freedom: The Dewey Lectures 1984 The Journal of Philosophy, 82, 4, April, 1985, 169-221.

Silva, M. R. (2008) Villas y asentamientos: mil estigmas en los medios in Cravino, M. C:, Del Rio, J. P., Duarte, J. I., Wagner, R. F., Graham, M. I., Ostuni, F., van Gelder, J., Silva, M. R., Varela, O. D. Los mil barrios (in)formales. Aportes para la construcción de un observatorio del habitat popular del Área Metropolitana de Buenos Aires, Universidad Nacional de General Sarmiento, Los Polvorines, Argentina.

Suárez, A. L. (2011) Segregación residencial en la Región Metropolitana de Buenos Aires in Balian, B. and Suarez, A.L. (comp.) Pobreza y solidaridad social en la Argentina. Aportes desde el enfoque de las capacidades humanas, Educa, Buenos Aires, pp. 39-72.

Techo (2013) Relevamiento de Asentamientos Informales 2013. Construcción Colectiva de la Información, Buenos Aires.

UN-Habitat (2013) Brochure Time to Think Urban.

http://www.unhabitat.org/pmss/listltemDetails.aspx?publicationID=3456 (consulted February 15, 2014).

UN-Habitat (2003a) The Challenge of Slums. Global Report on Human Settlements 2003, Earthscan, London.

UN-Habitat (2003b) UN-HABITAT's Policy Statement on Partnerships with NGOs \& Civil Society Organizations.

http://www.unhabitat.org/content.asp?typeid=19\&catid=364\&cid=372 (consulted March 17, 2014).

Wacquant, L. (2008) Urban Outcasts: A Comparative Sociology of Advanced Marginality, Polity Press, Cambridge, UK.

Ziccardi, A. (2008) Pobreza y exclusión social en las ciudades del siglo XXI in Ziccardi, A. (comp.) Procesos de urbanización de la pobreza y nuevas formas de exclusión social, CLACSO, Buenos Aires. 